\title{
sciendo
}

Folia Oeconomica Stetinensia

Volume 20 (2020) Issue 2

DOI: $10.2478 /$ foli-2020-0056
WYDZIAL NAUK EKONOMICZNYCH I ZARZA¿DZANIA

\section{THE DYNAMICS OF FOREIGN AID TRENDS AND PATTERNS \\ AMONG LOW- INCOME COUNTRIES IN AFRICA}

\author{
Mamo G. Tefera, $\mathrm{MSc}^{1}$ \\ Prof. Nicholas M. Odhiambo ${ }^{2}$ \\ University of South Africa \\ Department of Economics, \\ P.O Box 392, UNISA 0003, Pretoria, South Africa \\ 1e-mail:mg_mamo@yahoo.com \\ ORCID: 0000-0002-9000-2055 \\ ${ }^{2}$ e-mail:nmbaya99@yahoo.com \\ ORCID: 0000-0003-4988-0259
}

Received 24 December 2019, Accepted 5 October 2020

\begin{abstract}
Research background: Foreign aid flows to Africa mostly the Low-Income Countries (LICs) have increased drastically since 2000. Increasing aid flows are expected to stimulate economic growth that can release resources towards enabling LICs to reduce aid dependency.

Purpose: The purpose of this study is to discuss the dynamics of bilateral aid trends and patterns among 27 LICs in Africa during 2000-2017. The main question this study tries to answer is: how have aid sources, compositions and dependency changed in LICs?

Research methodology: The study employs a descriptive analysis technique to analyses bilateral aid flows to LICs in Africa from 50 donors during 2000-2017.

Results: Total net aid flows to LICs increased by 1.5 times during 2000-2017 and were predominantly in the form of grants $(92.7 \%)$. The study found a shift of sectoral aid allocations from the economic and productive sectors towards the social sector. Net aid as a share of GDP increased almost two-fold; implying an increasing trend of aid dependency in several LICs.

Novelty: This study tries to present a full account of bilateral aid flows both from Traditional Donors (TDs) and Non-Traditional Donors (NTDs), unlike many earlier studies that have focused on TDs.
\end{abstract}

Keywords: Foreign aid, sectoral aid allocation, Low-Income Countries, aid dependency, Africa

JEL classification: F35, N47, O55, Y10 


\section{Introduction}

The current concepts of foreign aid emerged in 1969 when the Development Assistance Committee (DAC) of the Organization for Economic Co-operation and Development (OECD) adopted Oversea Development Assistant (ODA) as the gold standards of foreign aid to measure concessional official financial flows to developing countries (OECD, 2006). In 1972, DAC provided a more refined definition of foreign aid as official flows composed of grants and concessional loans with a grant element of at least 25 percent and the primary aim is to promote economic development in aid recipient developing countries. Foreign aid flows is supposed to target the physical infrastructure in the economic and productive sectors to increase investment and support economic growth and reduce absolute poverty in developing countries (Chenery, Strout, 1966). Indeed, such rationale seemed to have guided sectoral aid compositions or allocations in the 1960s where more volume of aid was disbursed to direct growth-enhancing sectors. In terms of aid compositions by types, in 1978, the OECD DAC decided total aid should consist of grant aid of 90 percent for Least Developed Countries (LDCs) and 86 percent for developing countries. While grant aid is more conducive for poor countries or Low Income Countries (LICs) to avoid debt burden and support growth, loans are more conducive to encourage incentives for raising domestic resource mobilization (Morrissey, 2006; Colin, 2014). Overall, aid allocation either as grant or loan is guided by three criteria: aid recipient's income level (i.e. to use aid to the productive or social sectors); indebtedness level and the risk of debt stress (DI, 2013). The main motivation for this study rests on the dynamic changes on foreign aid disbursements since the turn of the $21^{\text {st }}$ century. First, despite aid disbursements are influenced by many factors, there has been a general shift of priority of aid allocation to poor countries or LICs. This is linked with a call for doubling aid for the poorest countries or LICs mostly in Africa since 2000 (as reflected in the 2002 Monterrey Conference and 2005 G-8 Gleneagles Summit). As a result, the volume and share of aid disbursed to poor countries or LICs has shown substantial rising trends since 2000. For instance, the share of aid flows to poor countries increased from 22 percent in 2000 to 35 percent in 2015 (Cilliers, 2017). This is about 59 percent growth rate or a 13 percentage point increase in the volume of aid flows to LICs over the last 15 year. Given that most of LICs (27 of 34 in 2017) are found in Africa, an increasing aid flows to Africa is not surprising. It was assumed that increasing aid flows would stimulate economic growth that can further release resources towards enabling poor African countries to reduce aid dependency (UNAIDS, 2005). This confirms that foreign aid continues to be a key resource for financing development in poor countries even in the Sustainable Development 
Goals (SDGs) era (OECD, 2017). Recent studies have shown that a higher share of aid flows to Africa went to the LICs, which suggests that not only aid remains critical but also a rising trends of aid dependency among these economies (Alemu, Lee, 2015; Pan, Tachega, Amowine, Ackaah, 2018; Bird, Choi, 2020). In the light of this, therefore, a clear understanding of such dynamics among LICs in Africa is imperative.

The second silent feature of foreign aid landscape since 2000 is the rising influence of NTDs alongside the TDs. The motivation that not all aid sources are unlike receives much attention mostly since 2000 associated with the new 'age of choice' among different sources of foreign aid mainly between Traditional Donors (TDs) and Non-Traditional Donors (NTDs) (Woods, 2008; Greenhill, Prizzon, Rogerson, 2013 ${ }^{1}$ ). Although TDs have remained a dominant source of aid since the $1960 \mathrm{~s}$, there is an increasing aid flows from NTDs since 2000 with a lion's share coming from China, and Africa received 45.7 percent of China's total foreign aid by the end of 2009. Therefore, extending the discussions on aid dynamics by considering total aid from both TDs and NTDs is critical to understand a genuine picture of total aid flows to Africa in general and LICs in particular. To the best of our understanding, however, no study has discussed the aid dynamic in LICs using total aid flow from TDs and NTDs.

Third, sectoral aid compositions have shown a rapid shift in the 2000s in relations to the MDGs and SDGs primary focus of poverty reduction in developing countries. Despite a shift of priority focus for poverty reduction since 2000, the primary motive of foreign aid remains unchanged and growth is a key parameter to evaluate aid-effectiveness. As noted above, the underline motive of foreign aid is to foster economic growth and reduce poverty in developing countries through targeting more aid flows to the economic and productive sectors. In 1967, for instance, around 64 percent of total aid went to the economic infrastructure projects $(27.8 \%)$ and productive sectors (36.6\%) (Broich, Szirmai, 2014). However, recent evidence reported a shift of sectoral aid distribution from the economic and productive sectors to the social sector (Akramov, 2012). This study found that the share of aid to the social sector has doubled since the 1980s and claimed over 40 percent in the early 2000s while the share dropped three-fold between the early 1980s (28-29\%) to the early 2000s (7-8\%). Although it did not present the figures by sectors, Alemu and Lee (2015) reported that aid flows to LICs in Africa mostly targeted the humanitarian and emergency needs while a very small share went to the economic sector. Perhaps, this could be seen as evidence of possible variations in sectoral aid allocations by the recipient's income-groups. However, a critical understanding of sectoral aid allocation to

\footnotetext{
1 We follow Greenhill et al. (2013, p. 22, footnote) and define TDs as synonymous to DAC member countries and NTDs as countries other than DAC members including those reporting their aid flows to the OECD and do not report.
} 
LICs in Africa is limited. Therefore, the main purpose of this study is to explore the dynamics of bilateral aid trends and patterns among LICs in Africa over the period 2000-2017 and to shed some useful insights about foreign aid dynamics in poor countries. The study focuses on African LICs because the continent hosts the majority (27 of the 34) LICs in developing countries, which could constitute a typical case for understanding the dynamics of aid flows to poor countries. More specifically, using bilateral aid flow during 2000-2017, this study aims to answer key questions such as: (i) how have aid trends in volumes (in absolute terms) and aid dependency evolved?, (ii) how have aid disbursements by main sources (TDs and NTDs) evolved?, and (iii) how have aid compositions by type (grants vs. loans) and sectors evolved? Overall, this study attempts to present a genuine picture of aid dynamics using total aid flows from both TDs and NTDs: the issue seemed to have been overlooked in most previous studies in favor of aid flows solely from TDs. A descriptive analysis method is employed to address the outlined research questions. The paper is organized under four sub-sections including the introduction. The introduction part provides a brief recap on related literatures on the concepts of foreign aid and its dynamics in relation to the research topic. Section 2 describes the data sources and methods of analysis. Section 3 presents the main findings of the study on the dynamics of bilateral aid flows in volumes, dependency, aid sources and compositions by type and sectors among LICs in Africa during 2000-2017. Section 4 concludes by way of summarizing the main findings and providing directions for further research.

\section{Research methodology}

This study uses bilateral foreign aid flows from both the TDs and NTDs. As of 2017, according to the OECD (2017), 49 donors (all 29 TDs and 20 NTDs) had reported their aid flows to the OECD while 10 NTDs did not. The OECD DAC database compiles annual aid flows for these 49 donors. Among the 10 NTDs that do not report to the OECD system, a full set of aid data is available only for China from the AidData online database. Thus, this study uses the OECD and AidData databases to compile aid flows from 50 donors. 9 NTDs that did not report to the OECD were excluded due to data unavailability. We apply the DAC aid definition to include aid flows from China. This is because aid flows from these NTDs (such as China) are not comprehensively defined (UNDP, 2016) and tend to mix both concessional and nonconcessional aid flows (UNESC, 2008). For China ${ }^{2}$ aid, therefore, only aid flows that qualify

\footnotetext{
2 China does not report its aid flows to the OECD system and aid flows from China are obtained from the AidData online database. AidData has compiled "ODA-like" (such as grants, interest- free loans, and concessional loans) global flows from China since 2000 and the latest to 2014 (constant 2014 USD). Unlike other studies that have used
} 
the DAC definition are collected from the AidData database. The debate whether the current definition of aid is narrow to accommodate broader aid packages from NTDs lies beyond the scope of this study. Net aid disbursement is the most common way to measure foreign aid flows and we use this measurement to analyze the overall aid flows to LICs. In terms of sectoral aid distributions, however, we use aid commitment because the OECD CRS database reports disaggregated sectoral aid distributions only as commitments. Data on GDP was obtained from the World Bank World Development Indicators (WDI). Given aid recipient countries are different in income and population size, raw aid does not appear to be informative unless it is measured in some form of ratio, either in terms of GDP or per capita. In the aid-growth nexus studies, most studies have measured aid as a share of GDP (Burnside, Dollar, 2000; Clemens, Radelet, Bhavnani, Bazzi, 2012; Juselius, Moller, Tarp, 2013; Arndt, Jones, Tarp, 2015; Dreher, Langtloz, 2017; Rahnama, Fawaz, Gittings, 2017). Aid to GDP ratio is preferred to per capita because most macroeconomic variables are expressed in terms of GDP and "the relative purchasing power of aid over a wide range of outcomes is best considered in economic terms, not in population terms" (Arndt et al., 2015, p. 9). We follow these studies and use the aid-to-GDP ratio in this study. Using a descriptive data analysis method, this study aims to answer a key question: how have the dynamics of foreign aid in volume, dependency, sources, and compositions evolved among LICs in Africa over the period 2000-2017?

\section{Main findings}

\subsection{The volume and share of net bilateral aid disbursements}

Over the last 18 years, bilateral foreign aid flows have increased substantially in Africa $(87 \%)$ in general and LICs (55\%) in particular. Table 1 displays the trends of net aid flows (excluding unspecified aid) to Africa and LICs in volumes and as a share of GDP during 2000 2017. Total net aid disbursements to Africa increased almost two-fold: from $\$ 13.7$ billion in 2000 to $\$ 25.7$ billion in 2017 . The largest share (90\%) of this aid came from TDs while NTDs also contributed about 10 percent; suggesting the rising influence of NTDs in Africa. The lion's share $(68.8 \%)$ of net aid flows to Africa went to LICs. In real terms, net aid flows increased by about \$6 billion from \$10.8 billion in 2000 to $\$ 16.7$ billion in 2017 .

\footnotetext{
"ODA-like" flows as foreign aid, we excluded interest- free loans as it does not qualify the DAC aid definition. Only the type of aid flows that qualify the DAC ODA criteria (grants and concessional loans with a grant element of at least 25\%) are extracted from AidData and included in this study.
} 
Table 1. Trends in net aid flows to Africa and LICs, in volume and share of GDP during 2000-2017 (Constant 2017 \$ billion; excluding unspecified aid flows)

\begin{tabular}{|c|c|c|c|c|c|}
\hline & \multicolumn{2}{|c|}{$\begin{array}{l}\text { Total net bilateral aid disbursed, \$ bn } \\
\text { (excl unspecified aid) }\end{array}$} & \multirow{2}{*}{$\begin{array}{c}\text { LIC's share } \\
\text { to total aid to } \\
\text { Africa }\end{array}$} & \multirow{2}{*}{$\begin{array}{l}\text { Aid to GDP } \\
\text { ratio }(\%), \\
\text { LICs }\end{array}$} & \multirow{2}{*}{$\begin{array}{l}\text { Aid to GDP } \\
\text { ratio }(\%), \\
\text { Africa }\end{array}$} \\
\hline & Africa & LICs & & & \\
\hline 2000 & 13.7 & 10.8 & 78.4 & 4.8 & 4.1 \\
\hline 2001 & 13.1 & 10.3 & 78.2 & 5.2 & 4.4 \\
\hline 2002 & 17.0 & 14.2 & 83.6 & 5.4 & 4.6 \\
\hline 2003 & 21.3 & 18.9 & 88.6 & 6.1 & 5.0 \\
\hline 2004 & 19.6 & 15.4 & 78.7 & 5.6 & 4.4 \\
\hline 2005 & 24.8 & 20.2 & 81.5 & 5.5 & 4.5 \\
\hline 2006 & 32.0 & 26.9 & 84.2 & 5.9 & 4.7 \\
\hline 2007 & 22.0 & 15.1 & 68.8 & 6.1 & 4.6 \\
\hline 2008 & 23.4 & 15.5 & 66.2 & 8.4 & 5.7 \\
\hline 2009 & 25.1 & 16.3 & 64.7 & 7.6 & 5.2 \\
\hline 2010 & 24.9 & 15.1 & 60.8 & 7.8 & 5.2 \\
\hline 2011 & 29.4 & 19.6 & 66.6 & 9.1 & 5.7 \\
\hline 2012 & 29.8 & 18.2 & 61.3 & 7.8 & 5.1 \\
\hline 2013 & 30.0 & 15.7 & 52.2 & 7.5 & 4.8 \\
\hline 2014 & 27.5 & 15.0 & 54.4 & 8.0 & 5.1 \\
\hline 2015 & 25.4 & 15.5 & 61.2 & 8.7 & 5.1 \\
\hline 2016 & 25.4 & 15.6 & 61.2 & 9.0 & 5.2 \\
\hline 2017 & 25.7 & 16.7 & 65.0 & 9.0 & 5.2 \\
\hline Total net aid, 2000-2017 & 430.1 & 295.0 & - & - & - \\
\hline Average net aid, 2000-2017 & 23.9 & 16.4 & 69.8 & 7.1 & 5.0 \\
\hline
\end{tabular}

Source: own elaboration.

Apart from a rising volume of aid flows, the rate of flows demonstrated substantial fluctuations. Figure 1 depicts the trends of aid flows in percentage changes and share in four different circumstances including the period before the global financial crisis (2000-2006); the crisis period (2007-2011); the post-crisis period (2012-2015) and the SDGs era (2016-2017). LICs received a lot of attention from donors in the early 2000s and during the SDGs era (20162017). On the other hand, LICs appeared to have received a relatively lower focus during the period of the global financial crisis. In terms of percent changes, the average rate of net aid flows to LICs was positive (18.8\%) before the crisis. 


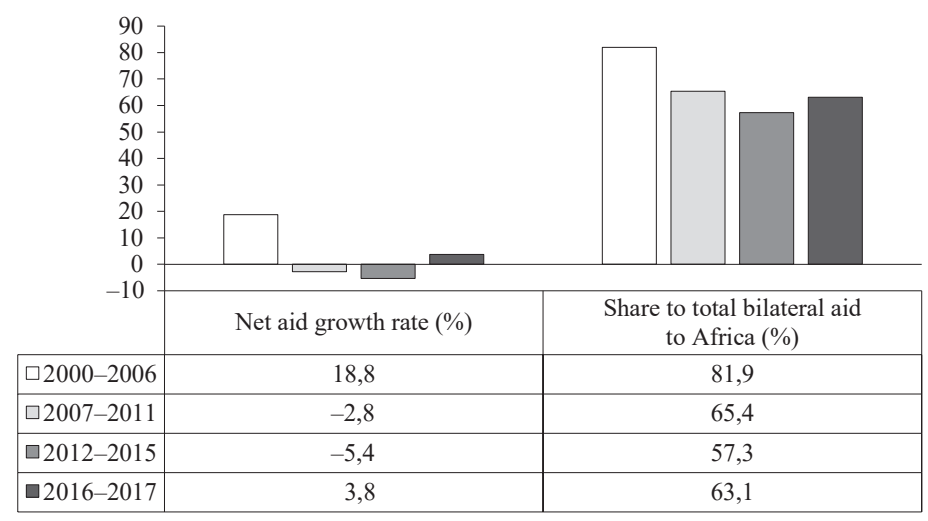

Figure 1. Net aid flows, in percentage change and share in LICs

Source: own elaboration.

On the contrary, the average net aid growth rate remained negative throughout the financial crisis period $(-2.8 \%)$ and the post-crisis period $(-5.4 \%)$. Furthermore, a similar story can be observed when the trends in the average share of net aid to total net aid flow to Africa is considered. The average share of aid was significantly higher during 2000-2006 (81.9\%) and steadily declined mostly since 2007 and afterward. Interestingly, LICs seemed to have received more attention in the post- 2015 SDGs period. This means that the focus on LICs tended to revive where aid flows took similar rising trends such as those of the early 2000 s. The study found upward trends of aid flows to LICs during 2016- 2017. On average, net aid increased by 3.8 percent in LICs and their share of total net bilateral aid disbursement to Africa increased to 63.1 percent. The most common way to measure the role of foreign aid in the recipient economy is to express aid as a share of GDP. The overall trends showed that the relative importance of foreign aid for financing economic development in LICs was increasing (see Table 1; Figures 2, 3). Net aid to GDP ratio in LICs averaged 7.8 percent between 2000 and 2017; almost 1.4 times the average to Africa (5\%). The share was increasing throughout the course of the study and peaked to 9.1 percent in 2011. It increased by 4.2 percentage points and 87.5 percent between 2000 (4.8\%) and 2017 (9\%). As a share of GDP, net aid amounted to more than 5 percent for the majority countries (17 from 27 countries or 63\%) in LICs (see Figure 2). The average share was more than 10 percent in 6 countries $(22.2 \%)$ implying relatively high aid dependency. Three countries (Somalia, Liberia and Mozambique) had an average aid to GDP ratio of 15 percent and above. 


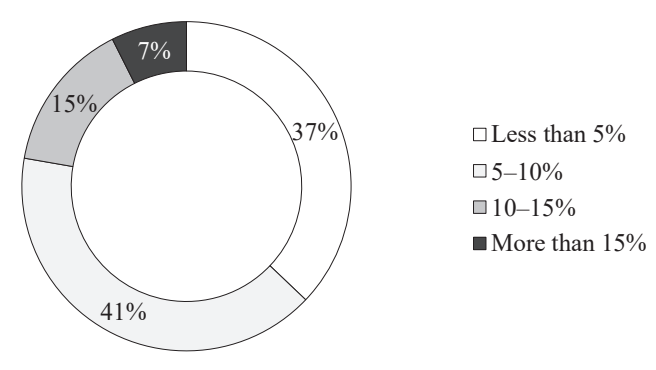

Figure 2. Average net aid to GDP ratio, 2000-2017, proportion of countries to all LICs

Source: own elaboration.

Further country level data revealed substantial variations across countries in LICs (Figure 3). The average share ranged between its lowest 2.5 percent in Guinea and the highest 44 percent in Somalia. In addition to Somalia, the average share amounted to more than 10 percent in Liberia (16.6\%), Mozambique (14.9\%), South Sudan (12.1\%), Burundi (11.1\%) and Sierra Leone (10.6\%). Indeed, this implies that these 6 countries continue to heavily rely on foreign aid for financing their economic development.



Figure 3. Overall average aid to GDP ratio in LICs during 2000-2017 (\%)

Source: own elaboration. 
Another striking finding is that receiving a larger share of aid does not necessarily lead to a situation of higher aid dependency. This is clearly seen when we evaluate countries which are the top and bottom 10 aid recipient countries among the LICs over the period 2000-2017 (Table 2). Except for Zimbabwe, foreign aid contributed to more than 5 percent of GDP for countries in the top 10 list. For 4 countries in the bottom 10 list, foreign aid amounted to over 5 percent of GDP. In short, it seems that aid dependency was manifested across countries despite the volume of net aid received.

Table 2. Top and bottom 10 aid recipients, in volume and share of GDP, 2000-2017

\begin{tabular}{|c|c|c|c|c|c|}
\hline \multicolumn{3}{|c|}{ Top 10 aid recipients } & \multicolumn{3}{|c|}{ Bottom 10 aid recipients } \\
\hline country & $\begin{array}{l}\text { total net aid, } \\
\$ \text { million }\end{array}$ & $\begin{array}{c}\text { average net aid to } \\
\text { GDP ratio }(\%)\end{array}$ & country & $\begin{array}{l}\text { total net aid, } \$ \\
\text { million }\end{array}$ & $\begin{array}{c}\text { average net aid to } \\
\text { GDP ratio }(\%)\end{array}$ \\
\hline Ethiopia & 28,701 & 5.9 & Sierra Leone & 4,594 & 10.6 \\
\hline Congo, DR & 27,335 & 7.8 & Chad & 4,415 & 2.7 \\
\hline Tanzania & 25,949 & 5.0 & Burundi & 3,899 & 11.1 \\
\hline Mozambique & 23,096 & 14.9 & Guinea & 3,055 & 2.5 \\
\hline Uganda & 16,886 & 5.3 & CAR & 2,243 & 7.8 \\
\hline Mali & 9,875 & 5.5 & Togo & 2,007 & 3.3 \\
\hline Somalia & 9,042 & 43.9 & Eritrea & 1,745 & 4.5 \\
\hline Zimbabwe & 8,795 & 3.5 & Guinea-Bissau & 952 & 6.6 \\
\hline Malawi & 8,402 & 7.4 & Gambia & 506 & 3.3 \\
\hline Rwanda & 7,294 & 7.7 & Comoros & 436 & 2.7 \\
\hline
\end{tabular}

Source: own elaboration.

Overall, we found evidence of an increasing trend in aid flows both in volumes (in absolute terms) as well as aid as percentage of GDP (i.e. aid dependency) among LICs in Africa during 2000-2017. These stylized facts may partly explain the reason why aid continues to be a key resource for most poor countries in Africa even in the SDGs period. Indeed, this clearly goes in line with arguments by the $\operatorname{OECD}(2017$, p. 138) that aid continues to play an important role in “filling key financing gaps where no alternatives exist" particularly in developing countries so as to support growth towards achieving SDGs by 2030. Moreover, studies have shown similar evidence of not only an increasing importance of foreign aid but also a rising trend of aid dependency among poor countries in Africa or LICs (Alemu, Lee, 2015; Mallik, 2008; Bird, Choi, 2019). 


\subsection{Trends in aid disbursements by main aid sources: TDs and NTDs}

Although foreign aid flows to Africa have come from 50 countries, there is substantial variation in terms of the volume of aid disbursed from the two main aid sources. As expected, TDs have remained a dominant source of aid and contributed about 97 percent of total aid disbursed to LICs in Africa over the study period. However, we found evidence in support of a growing relative importance of NTDs which contributed to about 3 percent of total aid disbursed to LICs over the study period. Out of the total net aid disbursed to Africa, the share of NTD's aid to LICs increased by 20 percent between 2000 (1.4\%) and 2017 (1.68\%) while TD's aid share to LICs increased by 15 percent between 2000 (47\%) and 2017 (54\%). Given NTDs are from developing countries and still some of them receiving aid from TDs, their growing role in Africa is highly encouraging. Besides, our results show a substantial variation of donor's (i.e. aid sources) across income groups in Africa. On average, LICs received the lion's share (57.7 percent) of aid flows from TDs while they received only about one-third $(30 \%)$ of aid flows from NTDs. Table 3 depicts the top 10 major donors to Africa in general and LICs in particular during 2000-2017.

Table 3. Top donors to Africa and LICs, in volume and share during 2000-2017

\begin{tabular}{|c|c|c|c|c|c|c|}
\hline \multicolumn{3}{|c|}{ Top 10 donors to Africa (2000-2017) } & \multicolumn{4}{|c|}{ Top 10 donors to LICs (2000-2017) } \\
\hline donors & $\begin{array}{c}\text { total net } \\
\text { bilateral aid } \\
\text { disbursed, } \\
\$ \text { billion }\end{array}$ & $\begin{array}{c}\text { share to total } \\
\text { net bilateral } \\
\text { aid to Africa } \\
(\%)\end{array}$ & donors & $\begin{array}{l}\text { total net } \\
\text { bilateral aid } \\
\text { disbursed, } \\
\$ \text { billion }\end{array}$ & $\begin{array}{c}\text { share to total } \\
\text { net bilateral } \\
\text { aid to LICs } \\
(\%)\end{array}$ & $\begin{array}{l}\text { share to total } \\
\text { net bilateral } \\
\text { aid to Africa } \\
(\%)\end{array}$ \\
\hline USA & 116.9 & 27.2 & USA & 81.7 & 27.7 & 19.0 \\
\hline France & 51.0 & 11.9 & UK & 35.6 & 12.1 & 8.3 \\
\hline UK & 43.6 & 10.1 & France & 26.6 & 9.0 & 6.2 \\
\hline Germany & 34.6 & 8.0 & Germany & 23.1 & 7.8 & 5.4 \\
\hline Japan & 22.3 & 5.2 & Japan & 16.4 & 5.6 & 3.8 \\
\hline China & 20.3 & 4.7 & Netherlands & 14.1 & 4.8 & 3.3 \\
\hline UAE & 17.3 & 4.0 & China & 12.9 & 4.4 & 3.0 \\
\hline Netherlands & 15.9 & 3.7 & Sweden & 10.8 & 3.7 & 2.5 \\
\hline Canada & 13.6 & 3.2 & Canada & 10.6 & 3.6 & 2.5 \\
\hline Sweden & 12.5 & 2.9 & Belgium & 9.4 & 3.2 & 2.2 \\
\hline Others & 82.2 & 19.1 & Others & 53.6 & 18.2 & 12.5 \\
\hline $\begin{array}{l}\text { Total net aid, } \\
2000-2017, \$ \text { bn }\end{array}$ & 430.2 & 100.0 & $\begin{array}{l}\text { Total net aid, } \\
2000-2017, \$ \text { bn }\end{array}$ & 295.0 & 100.0 & 68.6 \\
\hline
\end{tabular}

Source: own elaboration. 
Interestingly, 2 among the top 10 donors (China $-6^{\text {th }}$ and the United Arab Emirates $\left.7^{\text {th }}\right)$ to Africa are from the NTDs groups outside the DAC system. China contributed to 4.4 percent of total aid flows to LICs, suggesting that the rising role of NTDs in Africa has become prominent. The first three major TDs such as the USA (27.7\%), France (12.1\%) and the UK (9\%) have contributed to close to half (48.8\%) of total bilateral net aid flows to Africa over the course of the study. Overall, the lion's share of net aid disbursements to LICs came from the top 10 major donors, which constituted over 82 percent ( $\$ 241.4$ billion) of the total bilateral net aid disbursed to LICs (\$295 billion) during 2000-2017. This means that the other 40 donors are providing only 18 percent of total net aid flows to LICs. Overall, a relatively growing role of NTDs in LICs along with China being the top donor is consistent with relevant recent literature (Greenhill et al., 2013; UNCTAD, 2014; ECA, 2015). These studies have found evidence of an increasing importance of aid flows from NTDs in Africa with the lion's share coming from China.

\subsection{Trends in aid compositions during 2000-2017}

\section{Trends in aid compositions as grants and loans}

Foreign aid is disbursed in the form of grants and concessional loans. Figure 4 depicts the trends in the share of grants and loans aid compositions to total aid flows to LICs (Figure 4).

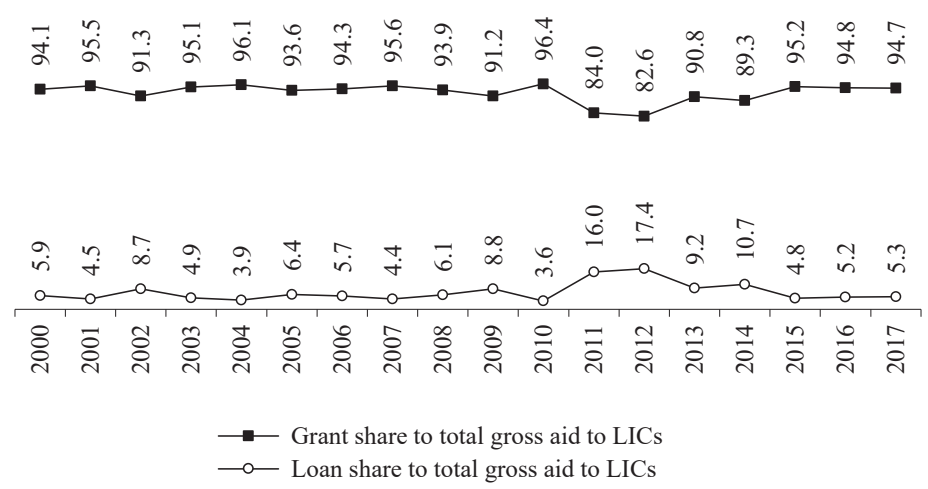

Figure 4. Trends in aid compositions, grants vs. loans, in LICs during 2000-2017 (\%) Source: own elaboration.

Consistent with the theories and empirical studies, grant aid constituted the lion's share (92.7\%) of total aid flows to LICs between 2000 and 2017. The share was substantially higher than the average for Africa (86\%). On average, LIC received about two-thirds (70 percent) 
of total bilateral grants disbursed to Africa between 2000 and 2017. On the contrary, the average loan's share of total gross aid to LICs amounted to 7.3 percent, almost twice lower than the Africa average of 14 percent. The average share in both aid compositions showed a stable trend throughout the study except for a steep fall in grants and rise in loans in 2011 and 2012.

Besides, a closer look into the top aid recipients shows the relative importance of grant aid compared to loans in LICs. Table 4 portrays the top and bottom 10 aid recipients in the form of grants and loans in LICs during 2000-2017.

Table 4. Top and bottom 10 recipients by aid compositions, in volume and share in LICs during 2000-2017 (\$ million)

\begin{tabular}{|c|c|c|c|c|c|c|c|}
\hline \multicolumn{4}{|c|}{ Top 10 recipients } & \multicolumn{4}{|c|}{ Bottom 10 recipients } \\
\hline \multicolumn{8}{|c|}{ Recipients of bilateral grant aid, 2000-2017 (\$ millions) } \\
\hline country & total grant & $\begin{array}{c}\text { share } \\
\text { of total grant } \\
\text { to Africa }(\%)\end{array}$ & $\begin{array}{c}\text { share } \\
\text { of GDP } \\
(\%)\end{array}$ & country & $\begin{array}{l}\text { total } \\
\text { grant }\end{array}$ & $\begin{array}{c}\text { share of total } \\
\text { grant to Africa } \\
(\%)\end{array}$ & $\begin{array}{c}\text { share } \\
\text { of GDP } \\
(\%)\end{array}$ \\
\hline Ethiopia & 26,777 & 6.69 & 5.1 & Congo, DR & 4,423 & 1.110 & 1.15 \\
\hline Tanzania & 23,959 & 5.99 & 4.3 & Burundi & 4,058 & 1.010 & 11.72 \\
\hline Mozambique & 21,486 & 5.37 & 12.4 & Chad & 3,710 & 0.930 & 2.23 \\
\hline Uganda & 16,434 & 4.11 & 4.9 & Guinea & 3,526 & 0.880 & 2.82 \\
\hline Mali & 10,112 & 2.53 & 5.7 & CAR & 2,358 & 0.590 & 7.70 \\
\hline Somalia & 9,079 & 2.27 & 47.6 & Togo & 2,150 & 0.540 & 3.47 \\
\hline Malawi & 8,731 & 2.18 & 7.7 & Eritrea & 1,682 & 0.420 & 4.04 \\
\hline Rwanda & 7,392 & 1.848 & 7.5 & Guinea-Bissau & 1,031 & 0.260 & 6.92 \\
\hline Zimbabwe & 7,390 & 1.847 & 2.9 & Gambia & 485 & 0.121 & 3.11 \\
\hline Burkina Faso & 7,303 & 1.83 & 4.7 & Comoros & 469 & 0.117 & 2.95 \\
\hline \multicolumn{8}{|c|}{ Recipients of bilateral gross loan aid, 2000-2017 (\$ millions) } \\
\hline country & total loan & $\begin{array}{c}\text { share of total } \\
\text { loan to Africa } \\
(\%)\end{array}$ & $\begin{array}{c}\text { share } \\
\text { of GDP } \\
(\%)\end{array}$ & country & $\begin{array}{l}\text { total } \\
\text { loan }\end{array}$ & $\begin{array}{c}\text { share of total } \\
\text { loan to Africa } \\
(\%)\end{array}$ & $\begin{array}{c}\text { share } \\
\text { of GDP } \\
(\%)\end{array}$ \\
\hline Tanzania & $2,661.8$ & 3.93 & 0.481 & Rwanda & 95.9 & 0.14000 & 0.1000 \\
\hline Mozambique & $2,524.8$ & 3.73 & 1.459 & Malawi & 86.2 & 0.13000 & 0.0800 \\
\hline Ethiopia & $2,339.4$ & 3.46 & 0.446 & Togo & 83.0 & 0.12000 & 0.1300 \\
\hline Zimbabwe & $1,476.3$ & 2.18 & 0.576 & Benin & 80.6 & 0.12000 & 0.0600 \\
\hline Congo, DR & 994.6 & 1.47 & 0.258 & Gambia & 73.4 & 0.11000 & 0.4700 \\
\hline Uganda & 913.1 & 1.35 & 0.272 & Burundi & 69.2 & 0.10000 & 0.2000 \\
\hline Chad & 843.1 & 1.25 & 0.508 & Guinea-Bissau & 5.6 & 0.00800 & 0.0400 \\
\hline Senegal & 662.1 & 0.98 & 0.233 & Comoros & 2.8 & 0.00400 & 0.0200 \\
\hline Burkina Faso & 416.4 & 0.62 & 0.268 & South Sudan & 1.7 & 0.00300 & 0.0021 \\
\hline Mali & 334.0 & 0.49 & 0.187 & CAR & 0.1 & 0.00012 & 0.0003 \\
\hline
\end{tabular}

Source: own elaboration. 
As a share of GDP, grant aid contributed to 5 percent and above for 8 countries among the top 10 recipients. Although stood as $5^{\text {th }}$ recipient, Somalia had the largest share of grant aid to GDP $(47.5 \%)$ followed by the $3^{\text {rd }}$ largest recipient, Mozambique $(12.4 \%)$. Interestingly, the share of grant aid to GDP constituted about 7 percent and above among the 3 least recipient countries such as Burundi (11.7\%), the Central African Republic (7.7\%) and Guinea-Bissau (6.9\%). This suggests that the importance of grant aid does not necessarily follow the volume of aid. On the other hand, the share of loan aid to GDP was lower than 1 percent in the 9 top recipients and all bottom recipients. Indeed, Somalia received no loans and total aid disbursed was in the form of a grant.

\section{Trends in sectoral aid distributions during 2000-2017}

In addition to aid compositions by types (i.e. grants and loans), aid compositions by sectors is another area of interest taken into account during aid disbursements. Figure 5 portrays the trends in sectoral aid distributions to the three important sectors such as social, economic and productive sectors. On average, a relatively higher volume of aid commitments (22.1\%) went to the social sector while the economic and productive sectors consumed an average share of 6.1 percent and 3.9 percent respectively.

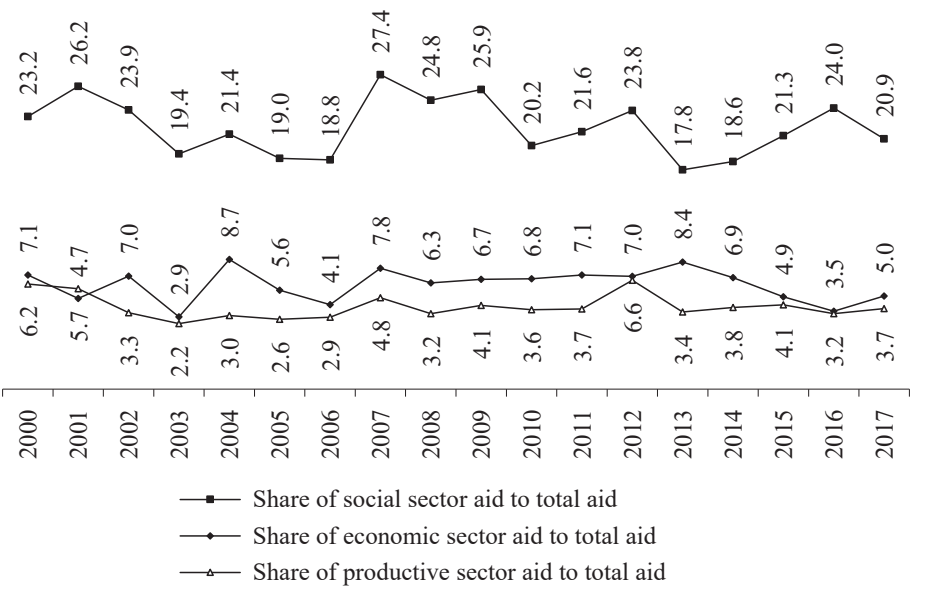

Figure 5. Trends in sectoral aid distributions to the three sectors in LICs as a share of total bilateral aid committed to all sectors and purposes in Africa during 2000-2017 (\%) Source: own elaboration.

Amazingly, the economic and productive sectors appeared to have received a much lower aid share than non-sectoral aid committed for debt relief (10.4\%) and humanitarian assistance 
(8.2\%). Indeed, LICs received the lion's share of aid committed for humanitarian support (72\%) and debt relief (80\%) in Africa over the study period.

Apart from this general picture, a closer look into the trends shows that the share of aid to all the three sectors was declining over the course of the study. The share in the social sector declined by 2.3 percentage points from 23 percent in 2000 to 21 percent in 2017. It also showed more fluctuations compared to the other two sectors. It initially increased to 26.2 percent in 2001, then slowed down before it peaked to 27.4 percent in 2007 and showed up and down declining trends afterward. Similar to the social sector, the average share in the economic sector declined by 2.1 percentage points from 7.1 percent in 2000 to 5 percent in 2017 . However, the share in the productive sector was declining significantly nearly by two-folds from 6.2 percent in 2000 to 3.7 percent in 2017. The share consistently declined except for the year 2012 where it reached 6.5 percent. Indeed, such a higher share was associated with a large amount of aid committed ( $\$ 1.4$ billion) to Tanzania in 2012. Overall, the falling trends in all the three sectors after 2007 could be seen as an account of reduced donors focus to LICs following the global financial crisis in 2007.

Furthermore, reviewing the top and bottom recipients of aid commitments to the three main sectors also exhibits similar evidence of sectoral aid distribution discussed above. Table 5 depicts the top and bottom recipients of aid committed to the three sectors in volume, as a share of GDP and a share of total aid commitments to Africa in each sector. Six countries (Tanzania, Ethiopia, Mozambique, Uganda, Mali, and Senegal) were the largest aid recipients in the three sectors. Surprisingly, Chad which appeared among the top recipients of aid to the economic sector was among the bottom lists in the social and productive sectors. Similarly, Liberia was found to be the top recipient of aid in the economic sector and bottom recipient in the productive sector. In terms of contribution to GDP, aid committed to the social sector appeared to be substantially higher compared to the other sectors. The average aid to GDP ratio among top recipients was higher in the social sector $(3.2 \%)$ than the economic $(1.1 \%)$ and productive $(0.7 \%)$ sectors. Interestingly, the average aid to GDP ratio among bottom recipients in the social sector $(2.1 \%)$ was by far higher than the average ratio in the other sectors. This suggests that foreign aid has been allocated towards financing the social sector in LICs over the course of the study. 
Table 5. Top and bottom 10 recipients of bilateral aid committed to the three sectors in LICs, in volume and share during 2000-2017

\begin{tabular}{|c|c|c|c|c|c|c|c|}
\hline \multicolumn{4}{|c|}{ Top 10 recipients } & \multicolumn{4}{|c|}{ Bottom 10 recipients } \\
\hline country & $\begin{array}{c}\text { total } \\
\text { aid }\end{array}$ & $\begin{array}{l}\text { share of aid } \\
\text { to Africa }(\%)\end{array}$ & $\begin{array}{c}\text { share } \\
\text { of GDP }(\%)\end{array}$ & country & $\begin{array}{l}\text { total } \\
\text { aid }\end{array}$ & $\begin{array}{l}\text { share of aid } \\
\text { to Africa }(\%)\end{array}$ & $\begin{array}{c}\text { share } \\
\text { of GDP } \\
(\%)\end{array}$ \\
\hline \multicolumn{8}{|c|}{ Aid committed to social infrastructure and services in LICs, 2000-2017 (\$ billions) } \\
\hline Tanzania & 12.9 & 6.70 & 2.33 & Sierra Leone & 1.800 & 0.9200 & 3.90 \\
\hline Mozambique & 11.5 & 6.00 & 6.64 & Burundi & 1.700 & 0.9000 & 5.00 \\
\hline Ethiopia & 10.80 & 5.60 & 2.10 & Guinea & 1.500 & 0.8000 & 1.20 \\
\hline Uganda & 10.00 & 5.20 & 3.00 & Chad & 0.800 & 0.4100 & 0.50 \\
\hline Congo, DR & 6.90 & 3.60 & 1.80 & Togo & 0.700 & 0.3700 & 1.10 \\
\hline Mali & 5.70 & 2.90 & 3.20 & CAR & 0.500 & 0.2700 & 1.67 \\
\hline Senegal & 5.30 & 2.80 & 1.90 & Eritrea & 0.470 & 0.2500 & 1.10 \\
\hline Malawi & 5.10 & 2.60 & 4.46 & Guinea-Bissau & 0.450 & 0.2300 & 3.00 \\
\hline Zimbabwe & 4.70 & 2.50 & 1.80 & Comoros & 0.300 & 0.1400 & 1.74 \\
\hline Rwanda & 4.40 & 2.30 & 4.47 & Gambia & 0.250 & 0.1300 & 1.60 \\
\hline \multicolumn{8}{|c|}{ Aid committed to economic Infrastructure and services in LICs, 2000-2017 (\$ billions) } \\
\hline Tanzania & 4.66 & 6.40 & 0.84 & South Sudan & 0.300 & 0.4440 & 0.40 \\
\hline Mozambique & 4.31 & 5.90 & 2.50 & Burundi & 0.250 & 0.3360 & 0.70 \\
\hline Ethiopia & 3.78 & 5.20 & 0.72 & Togo & 0.240 & 0.3280 & 0.40 \\
\hline Zimbabwe & 2.20 & 2.96 & 0.80 & Guinea & 0.170 & 0.2260 & 0.10 \\
\hline Uganda & 2.10 & 2.81 & 0.60 & Somalia & 0.109 & 0.1485 & 0.60 \\
\hline Senegal & 1.70 & 2.38 & 0.60 & Gambia & 0.108 & 0.1483 & 0.70 \\
\hline Liberia & 1.10 & 1.48 & 3.10 & Eritrea & 0.106 & 0.1450 & 0.30 \\
\hline Benin & 0.90 & 1.25 & 0.70 & Comoros & 0.104 & 0.1420 & 0.70 \\
\hline Mali & 0.89 & 1.22 & 0.50 & CAR & 0.096 & 0.1320 & 0.30 \\
\hline Chad & 0.85 & 1.17 & 0.50 & Guinea-Bissau & 0.030 & 0.0420 & 0.20 \\
\hline \multicolumn{8}{|c|}{ Aid committed to the productive sector in LICs, 2000-2017 (\$ billions) } \\
\hline Tanzania & 2.86 & 8.0 & 0.50 & South Sudan & 0.310 & 0.87 & 0.40 \\
\hline Ethiopia & 2.49 & 6.9 & 0.47 & Liberia & 0.230 & 0.65 & 0.70 \\
\hline Mali & 1.73 & 4.8 & 1.00 & Chad & 0.190 & 0.52 & 0.10 \\
\hline Mozambique & 1.58 & 4.4 & 0.90 & Togo & 0.140 & 0.38 & 0.20 \\
\hline Senegal & 1.51 & 4.2 & 0.50 & Sierra Leone & 0.120 & 0.34 & 0.30 \\
\hline Uganda & 1.32 & 3.7 & 0.40 & Somalia & 0.110 & 0.30 & 0.60 \\
\hline Burkina Faso & 1.20 & 3.2 & 0.75 & CAR & 0.076 & 0.21 & 0.25 \\
\hline Malawi & 0.86 & 2.4 & 0.75 & Gambia & 0.041 & 0.11 & 0.30 \\
\hline Rwanda & 0.79 & 2.2 & 0.80 & Guinea-Bissau & 0.037 & 0.10 & 0.25 \\
\hline Benin & 0.70 & 1.9 & 0.60 & Comoros & 0.017 & 0.05 & 0.10 \\
\hline
\end{tabular}

Source: own elaboration. 
By and large, this evidence on aid composition by types goes in line with the convention in aid allocation where 90 percent of aid flows to LICs should be in grant form. Regarding sectoral aid allocation, a key implication of this finding is that the shift of aid allocation away from the broader economic growth objectives could directly affect financing economic development in LICs. Indeed, our findings are consistent with recent literature that documented similar evidence of a general shift of sectoral aid allocations in developing countries (Akramov, 2011) and LICs in Africa (Alemu, Lee, 2015).

\section{Conclusion and Directions for Further Research}

This paper presented a descriptive discussion on the dynamics of foreign aid trends and patterns among 27 LICs in Africa between 2000 and 2017. Based on net bilateral aid flows from both TDs and NTDs, the paper seeks to explore how the volume of aid flows (by sources), aid dependency and aid compositions (by types and sectors) have evolved among LICs in Africa. The main findings and implications of this study can be summarized as follows.

First, this paper found evidence of an increasing trend in bilateral aid flows not only in volumes (in absolute terms) but also as a percentage of GDP (i.e. aid dependency). We found that total net aid disbursements to African LICs increased by 1.5 times; from $\$ 10.8$ billion in 2000 to $\$ 16.7$ billion in 2017. On average, LICs consumed the lion's share $(69.8 \%)$ of total net aid disbursed to Africa. Besides, the study found rising trends of aid dependence with aid contributed to a significant share of GDP for several of the LICs. The average aid dependency in LICs was 7.8 percent: almost 1.4 times the average to Africa (5\%). Overall, these stylized facts may partly explain the reason why aid continues to be a key resource for most poor countries in Africa even in the SDGs period. Indeed, our finding goes in line with the recent literature of (Alemu, Lee, 2015; Mallik, 2008; Pan et al., 2018; Urtuzuastigui, 2019; Bird, Choi, 2020). These studies have documented similar evidence of an increasing trend in foreign aid flows both in terms of volume and as a percentage of GDP or aid dependence among African poor countries or LICs.

Second, a novel finding of this study is that the focus of aid sources have shown substantial variations across income-groups in Africa where LICs received the lion's share (57.7 percent) of TD's aid while they received only about one-third (30\%) of NTD's aid. Overall, our findings show evidence of a marginal growing role of NTDs since 2000 alongside the TDs (i.e. the dominant aid sources since the 1960s). Besides, we also found that one among the top ten donors to LICs was from NTDs (i.e. China). Although they did not report by income-groups, 
our findings are consistent with recent literature that reported an increasing role of NTDs in Africa since 2000 alongside TDs with China provided the lion's share of NTD's aid (Greenhill et al., 2013; UNCTAD, 2014). Thus, NTDs could be seen as potential additional sources of aid alongside TDs and governments in LICs should leverage for increasing aid flows from both donors. Third, another key finding shows that there is a substantial shift of sectoral aid allocations away from the growth-enhancing sectors in LICs since 2000 due mainly to the strong focus on achieving the MDGs. While the social sector received a larger share of aid (22.1\%), the economic and productive sectors received only 6.1 percent and 3.9 percent respectively, a much lower share than the non-sectoral aid allocation for debt relief (10.4\%) and humanitarian assistance (8.2\%). Our findings are consistent with recent literature that documented similar evidence of a general shift of sectoral aid allocations in developing countries (Akramov, 2011) and LICs in Africa (Mallik, 2008; Alemu, Lee, 2015). Akramov (2011) found that share of aid to social sectors doubled since the 1980 s and reached over 40 percent in the early 2000 s while it dropped three-fold for the economic and productive sectors over the same period. Although the share of aid went to the social sector is not reported, recent studies have shown that aid flows to LICs in Africa mostly targeted for humanitarian purpose (i.e. food and emergency needs) while the productive and economic sectors received a very small share of it (Mallik, 2008; Alemu, Lee, 2015). By and large, a key implication of our findings is that the shift of aid allocation away from the broader growth objectives could directly affect financing economic development in LICs. Overall, our main findings are somehow comparable to some recent studies in this area of research. However, these studies seemed to have focused either on aid flows to LICs solely from TDs or on both TDs and NTDs in Africa without specific reference to LICs. Whereas, our study has focused on LICs and extended the discussion of aid flows from both TDs and NTDs so as to present a genuine picture on total bilateral aid flows to these economies. On the other hand, our study focuses on the general trends of aid flows from both donors and did not present an analysis on aid compositions disaggregated by aid sources (i.e. TDs and NTDs). Therefore, we recommend that a relevant area for further research could be exploring: (i) how aid compositions by types (grants and loans) and sectors have evolved across the two main aid sources (i.e. TDs and NTDs); and (ii) what major factors contribute to the increasing trend in aid dependency among LICs in Africa. 


\section{References}

AidData (2017). Global Chinese Official Finance Dataset, Version 1.0. Retrieved from: http:// aiddata.org/data/chinese-global-official-finance-dataset (9.05.2019).

Akramov, K. (2012). Foreign aid allocation, governance and economic growth. IFPRI issue brief (72), November 2012. Washington, DC. International Food Policy Institute (IFPRI). DOI: $10.2499 / 9780896298095$.

Alemu, A.M., Lee, J. (2015). Foreign aid on economic growth in Africa: a comparison of low and middle-income countries. SAJEMS NS, 18 (4), 449-462. DOI: 10.17159/22223436/2015/V18N4A1

Arndt, C., Jones, S., Tarp, F. (2015). Assessing foreign aid's long-run contribution to growth and development. World Development, 69, 6-18. DOI: 10.1016/j.worlddev.2013.12.016.

Bird, G., Choi, Y. (2020). The effects of remittances, foreign direct investment, and foreign aid on economic growth: An empirical analysis. Rev Dev Econ, 24,1-30. DOI: 10.1111/ rode. 12630 .

Burnside, C., Dollar, D. (2000). Aid, policies, and growth. American Economic Review, 90 (4), 847-868. DOI: 10.1257/aer.90.4.847.

Broich, T., Szirmai, B. (2014). China's Economic Embrace of Africa - An International Comparative Perspective. Paper presented at the UNU-MERIT conference 26-28 November 2014. Maastricht University.

Chenery, H.B., Strout, A.M. (1966). Foreign assistance and economic development. The American Economic Review, LVI (4/1). Retrieved from: https://www.jstor.org/stable/1813524 (1.09.1966).

Cilliers, J. (2017). Fertility, growth and the future of aid in Sub-Saharan Africa. Institute for Security Studies, October 2017. Retrieved from: http://issafrica.s3.amazonaws.com/site/ uploads/aitwr-6-2.pdf.

Clemens, M.A., Radelet, S., Bhavnani, R.R., Bazzi, S. (2012). Counting Chickens when they hatch: timing and the effect of aid on growth. The Economic Journal, 122 (June), 590617. DOI: 10.1111/j.1468-0297.2011.02482.x.

Colin, S. (2014). A matter of high interest: Assessing how loans are reported as development aid. Eurodad, report. January 2014, Belgium. Retrieved from: https:/www.columban.jp/ upload_files/data/DE0067_HighInterestEuroDad.pdf.

DI (Development Initiatives) (2013). ODA loans: Investment to end poverty. Discussion Paper. February, 2013. UK. Retrieved from: http://devinit.org/wp-content/uploads/2013/09/ ODA-loans-discussion-paper-v1.0-22.pdf. 
Dreher, A., Langlotz, S. (2017). Aid and growth. New evidence using an excludable instrument. Discussion Paper Series, No. 65, June. Heidelberg University. DOI: 10.11588/heidok.00023147.

ECA (Economic Commission for Africa) (2015). Economic Report on Africa 2015: Industrializing through trade. United Nations Economic Commission for Africa (UNECA), Addis Ababa, Ethiopia.

Greenhill, R., Prizzon, A., Rogerson, A. (2013). The age of choice: how are developing countries managing the new aid landscape? ODI Working Paper, March, London. DOI: 10.1057/978-1-137-55357-7_10.

Juselius, K., Moller, N.F., Tarp, F. (2013). The long run impacts of foreign aid in 36 African countries: insights from multivariate time series analysis. Oxford Bulletin of Economics and Statistics, 76 (2). DOI: 10.1111/obes.12012.

Mallik, G. (2008). Foreign Aid and Economic Growth: A Cointegration Analysis of the Six Poorest African Countries. Economic Analysis \& Policy, 38 (2). DOI: 10.1016/S03135926(08)50020-8.

Morrissey, O., Islei, O., M'Amanja, D. (2006). Aid Loans Versus Aid Grants: Are the Effects Different? CREDIT Research Paper, 06/07. University of Nottingham. Retrieved from: http://hdl.handle.net/10419/80305.

OECD (Organization for Economic Cooperation and Development) (2006). DAC in Dates: the history of OECD's Development Assistance Committee. 2006 edition, OECD, Paris.

OECD (Organization for Economic Cooperation and Development) (2017). Development Cooperation Report 2017: Data for Development. OECD Publishing, Paris.

OECD (Organization for Economic Cooperation and Development) (2019). DAC Statistics. Retrieved from: www.oecd.org/dac/stats/idsonline (29.04.2019).

Pan, S., Tachega, M.A., Amowine, N., Ackaah, W. (2018). The Relationship between Foreign Aid and Growth: A comparative Analysis of Low Income, Lower-Middle Income and Upper-Middle Income African Countries. Journal of Economic and Sustainable Development, 9 (6). Retrieved from: https://www.iiste.org/Journals/index.php/JEDS/article/ view/41685.

Rahnama, M., Fawaz, F., Gittings, K. (2017). The effects of foreign aid on growth in developing countries. The Journal of Developing Areas, 51 (3), 153-171. Retrieved from: https:// ideas.repec.org/a/jda/journl/vol.51year2017issue3pp153-171.html.

UNCTAD (United Nations Conference on Trade and Development) (2014). The Least Developed Countries Report. Growth with structural transformation: A post-2015 development agenda. United Nations. Retrieved from: https://unctad.org/en/pages/PublicationWebflyer.aspx?publicationid $=1067$.

UNDP (United Nations Development Program) (2016). Concessional Financial Flows among Southern Countries: Conceptualizing, Design, Principles, Operational Modalities and an 
Assessment Framework. October 2016, New York USA. Retrieved from: https://cpd.org. bd/concessional-financial-flows-among-southern-countries.

UNESC (United Nations Economic and Social Council) (2008). Trends in South-South and triangular development cooperation. Background paper for the development cooperation forum, April 2008. Retrieved from: https://www.un.org/en/ecosoc/docs/pdfs/south-south cooperation.pdf.

UNAIDS (United Nations Program on HIV/AIDS) (2005). Summit document on Africa: G8 Gleneagle Summit. Retrieved from: http://data.unaids.org/topics/universalaccess/postg8 gleneagles_africa_en.pdf.

Urtuzuastigui, G.A. (2019). Bilateral aid in sub-Saharan Africa: are donor delivery tactics stimulating economic growth and development? Journal of Contemporary African Studies, 37 (1), 128-147. DOI: 10.1080/02589001.2018.1541502.

World Bank (2019). World Development Indicators 2019, Washington, DC: World Bank. Retrieved from: https://datacatalog.worldbank.org/dataset/world-development-indicators. 